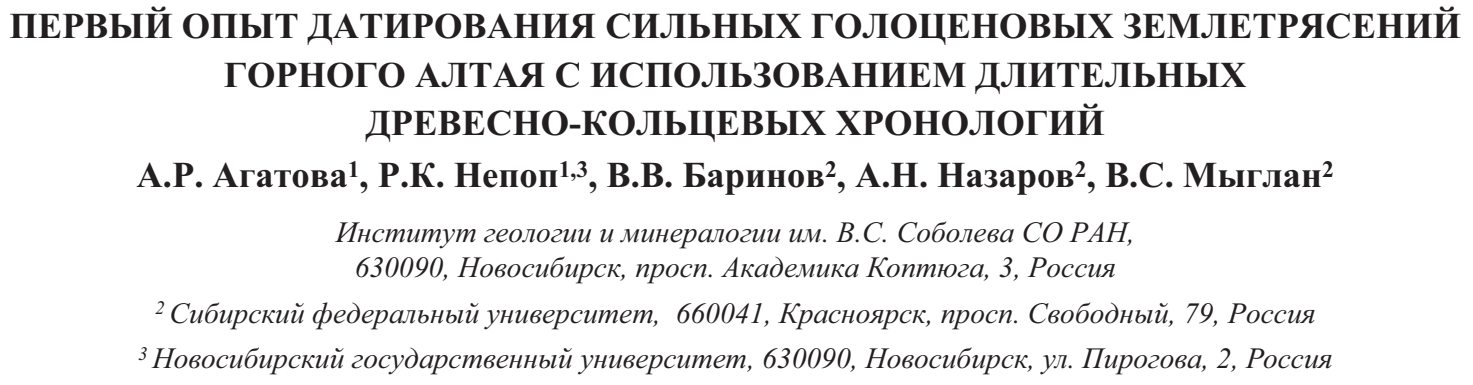

Приведены первые результаты применения длительных древесно-кольцевых шкал для датирования сейсмоиндуцированных камнепадов и верхней временно́й границы формирования голоценовых сейсмообвалов на территории Юго-Восточного Алтая. В рамках дендросейсмохронологии впервые предложено и опробовано датирование проникающих травм древесины, сформулирован критерий выделения сейсмоиндуцированных камнепадов среди склоновых процессов климатической природы. Установлено ранее неизвестное сильное средневековое землетрясение 1532 г., следы которого были датированы также радиоуглеродным методом. На основании вновь полученных данных и калибровки радиоуглеродных дат, опубликованных ранее, уточнен период повторяемости сильных землетрясений на территории ЮВ Алтая.

Дендрохронологический анализ, длительные древесно-кольцевые хронологии, сейсмоиндуцированные склоновые прочессы, палеосейсмичность, голочен, Алтай.

\title{
THE FIRST DATING OF STRONG HOLOCENE EARTHQUAKES IN GORNY ALTAI USING LONG-TERM TREE-RING CHRONOLOGIES
}

\section{A.R. Agatova, R.K. Nepop, V.V. Barinov, A.N. Nazarov, and V.S. Myglan}

We present the first results of application of long-term tree-ring chronologies for dating seismically triggered rockfalls and determining the upper age of Holocene rockfalls in southeastern Altai. Based on the results of seismic dendrochronological analysis, dating of penetrating wood injuries is proposed and tested, and the criterion for the distinguishing of seismically triggered rockfalls among slope processes of climatic nature is formulated. An earlier unknown strong earthquake of 1532 has been recognized; its traces are dated by the radiocarbon method. Based on the new data and calibration of earlier radiocarbon dates, the recurrence period of strong earthquakes in the southeastern Altai is refined.

Dendrochronological analysis, long-term tree-ring chronologies, seismically triggered slope processes, paleoseismicity, Holocene, Altai

\section{ВВЕДЕНИЕ}

Одной из основных проблем при сейсмическом районировании и выделении территорий с высоким уровнем сейсмической активности является установление значений максимально возможной магнитуды и периода повторяемости сильных землетрясений, наиболее разрушительных и опасных для человека. Продолжительность инструментальных сейсмологических наблюдений невелика по сравнению с периодом повторяемости сильных землетрясений, и для расчета этой величины привлекаются исторические данные, а также определяется время возникновения выявленных на изучаемой территории палеосейсмодислокаций [Солоненко, 1966; Paleoseismology, 2009].

Среди методов абсолютного датирования древних сейсмодислокаций в настоящее время наиболее часто используется радиоуглеродный анализ. Он позволяет датировать почвы, фрагменты древесины и другие органические материалы, деформированные и захороненные во время землетрясений и/или перекрывающие сейсмогенные разрывы и обвалы/оползни.

Предел датирования радиоуглеродного анализа составляет около 50 тыс. лет (при изотопном обогащении ${ }^{14} \mathrm{C}-$ до $\sim 75$ тыс. лет), однако его использование для определения возраста сейсмособытий последних 2-3 тыс. лет, т.е. на ближайшем к современности временном отрезке, имеет ряд ограничений. Они связаны с высокой относительной погрешностью радиоуглеродного метода на этом интервале и наличия ряда «плато» на калибровочной кривой, затрудняющих привязку радиоуглеродных дат к ка- 
лендарной шкале [Вагнер, 2006] ${ }^{1}$. Так, проведенное нами сопоставление дендрохронологических и радиоуглеродных датировок одних и тех же образцов древесины из моренных отложений в долинах Горного Алтая показало, что радиоуглеродный метод на интервале последних 3 тыс. лет может давать ошибку определения возраста древесины, наилучшего материала для данного вида датирования, до 300 лет. Такая ошибка уже сравнима по величине с периодом повторяемости сильных землетрясений Горного Алтая в голоцене, определенным с применением радиоуглеродного метода - 500-900 лет [Рогожин и др., 2007]. Кроме того, радиоуглеродные даты палеопочв дают представление лишь об осредненном времени их формирования, что также значительно снижает точность определения возраста сейсмодислокаций.

При наличии в сейсмоактивных зонах древесной растительности дополнением, а иногда и альтернативой радиоуглеродному методу, может служить дендрохронологический анализ, который дает возможность датировать события с точностью до года, а иногда даже до сезона. В мировой сейсмологической практике с целью датирования землетрясений до настоящего времени использовалось несколько аспектов дендрохронологического анализа. Для определения времени возникновения разрывных нарушений проводилось: 1) датирование первичных дендросейсмологических свидетельств - разрывов стволов, корней деревьев, а также крена и вывала деревьев в зоне поверхностных сейсморазрывов; 2) датирование вторичных свидетельств - начала замедленного роста и/или гибели деревьев вдоль сейсморазрывов, связанных с полной или частичной потерей кроны в результате сотрясения поверхности. Для датирования оползней и обвалов с доказанной сейсмической природой формирования изучается древесина деревьев-свидетелей, произрастающих непосредственно на теле оползня (начало формирования креневой древесины соответствует времени сейсмособытия); определяется минимальный возраст обвала/оползня (по возрасту самого старого дерева, выросшего на теле обвала либо стенке его отрыва), а также устанавливается точная дата подвижки (по времени гибели погребенных обвалом/оползнем деревьев) [Paleoseismology, 2009]. В России дендрохронологический анализ был успешно применен при изучении сейсмичности Станового нагорья для датирования землетрясений по времени гибели деревьев и формирования креневой древесины у деревьев-свидетелей в зонах разрывных нарушений [Ружич и др., 1982].

Подчеркнем, что временной интервал применения дендрохронологического анализа для датирования сейсмодислокаций до сих пор ограничивался возрастом древостоя последнего поколения, и наиболее эффективно этот метод был использован для определения возраста сейсмособытий не древнее 300 лет. В то же время дендрохронологический анализ, основанный на уникальности сочетания ширины годичных колец в конкретной местности, позволяет проводить датирование любых событий, связанных с повреждением, гибелью и захоронением деревьев либо с появлением новой генерации леса на вновь образованных поверхностях, на интервале, существенно превышающем возраст современного древостоя. Этот интервал определяется длительностью региональных абсолютных древесно-кольцевых шкал, к которым можно привязывать относительные древесно-кольцевые хронологии (дкх), созданные при анализе палеодеревьев, произраставших на исследуемых сейсмодислокациях голоценового возраста. В настоящее время существует несколько абсолютных региональных хронологий, однако датирование голоценовых землетрясений с помощью этих д.к.х. в мировой практике дендросейсмологии не проводилось.

В статье приводятся первые результаты датирования сильных голоценовых землетрясений в наиболее сейсмоактивной юго-восточной части Горного Алтая, основанного на применении длительных древесно-кольцевых шкал [Агатова и др., 2014].

\section{ПЕРСПЕКТИВЫ ПРОВЕДЕНИЯ ДЕНДРОХРОНОЛОГИЧЕСКОГО ДАТИРОВАНИЯ СЕЙСМОИНДУЦИРОВАННЫХ ФОРМ РЕЛЬЕФА НА ТЕРРИТОРИИ ЮВ АЛТАЯ}

В новейшей структуре Алтайского шовного поднятия юго-восточная часть Горного (Русского) Алтая (ЮВ Алтай) представляет собой транспрессионную зону сейсмогенерирующих правых сдвигов, протягивающихся из Монгольского Алтая [Новиков, 2004; Ребецкий и др., 2013]. В пределах ЮВ Алтая происходит значительное дробление литосферы и перемещение крупных блоков-хребтов по субширотным взбросам и надвигам. Это наиболее высокогорная (до 3500-4500 м над ур.м.) и сейсмически-активная территория в пределах российской части Алтая. Именно здесь произошло Чуйское землетрясение 2003 г. $\left(M_{s}=7.3\right)$ [Высоцкий и др., 2004; Лескова, Еманов, 2013] и выявлены следы многочисленных сильных голоценовых землетрясений [Бутвиловский, 1993; Рогожин, Платонова, 2002; Агатова и др., 2006; Рогожин и др., 2007]. Вследствие значительной расчлененности рельефа одними из характерных

1 Заметим, что разбавление концентрации атмосферного ${ }^{14} \mathrm{C}$ вследствие начавшейся в середине ХІХ в. индустриализации (эффект Зюсса) вообще не позволяет датировать радиоуглеродным методом образцы моложе 1850 г. [Вагнер, 2006]. 
следов сильных палеоземлетрясений в ЮВ Алтае являются крупные обвалы и оползни, сохраняющиеся благодаря аридному климату в течение тысячелетий. Количество осадков на днище межгорных впадин в пределах ЮВ Алтая не превышает 200 мм/год, возрастая к гребням хребтов, при этом их абсолютное значение убывает с запада на восток от 2000 до 500 мм/год и менее [Нарожный, Осипов, 1999]. Распределение лесной растительности подчеркивает незначительное количество осадков и аридизацию климата в восточном направлении. В горном обрамлении Курайской впадины пояс кедрово-лиственничного леса протягивается на северном макросклоне Северо-Чуйского хребта до высоты 2350-2450 м над ур. м. В западной части Чуйской впадины распространены лишь редкие островки лиственничников. Участки взрослого леса ограничены здесь высотами 2220-2330 м над ур.м., отдельные деревья и молодой подрост встречаются вплоть до 2500 м. В юго-восточной части Чуйской впадины, в пределах северного макросклона хр. Сайлюгем, лесная растительность уже отсутствует.

Успешное использование дендрохронологического анализа для датирования сейсмоиндуцированных палеообвалов, оползней и камнепадов на территории ЮВ Алтая обусловлено несколькими причинами:

1. Значительная часть сейсмообвалов и оползней расположена на высоте, близкой к верхней границе леса. Именно на этом уровне климатический сигнал максимально отражен в характере прироста древесины, что необходимо для построения длительных древесно-кольцевых шкал и датирования отдельных палеодеревьев, пострадавших в ходе землетрясений и/или заселивших новообразованные поверхности. Необходимо подчеркнуть, что вследствие колебаний температуры верхняя граница леса в ЮВ Алтае в течение голоцена неоднократно поднималась выше ее современного положения [Назаров и др., 2012].

2. В условиях аридного климата древесина погибших деревьев может сохраняться на каменной поверхности до 2 тыс. лет, что также способствует построению длительных локальных и региональных Д.К.Х.

3. Несколько лет назад для ЮВ Алтая и Тувы была создана сеть абсолютных дендрохронологий по лиственнице (Larix sibirica Ledeb) и сосне сибирской (Pinus sibirica Du Tour), максимальной из которых является 2367-летняя д.к.х. Mongun [Мыглан и др., 2012]. Для Сибири, помимо Ямальской, Таймырской, Индигирской, это четвертая хронология протяженностью более 2000 лет. Два года назад с ней удалось соединить «плавающую» 424-летнюю д.к.х. археологической древесины из пазырыкских курганов ЮВ Алтая [Слюсаренко, 2010]. Таким образом, в настоящее время дендрохронологический метод на территории ЮВ Алтая и Тувы может быть использован для датирования сейсмособытий возрастом до 2720 лет. Об уникальности нового инструмента датирования говорит тот факт, что помимо сибирских хронологий существуют всего лишь четыре длительные д.к.х., построенные для Центральной Европы, Ирландии, Америки и Китая.

4. Произошедшее в 2003 г. Чуйское землетрясение с $M_{s}=7.3$ предоставило редкую возможность для сравнительного анализа распределения сейсмоиндуцированных травм древесины современных и палеодеревьев в пределах ЮВ Алтая.

\section{ОБЪЕКТ ИССЛЕДОВАНИЯ}

Метод дендрохронологического датирования палеоземлетрясений был опробован нами при исследовании ранее неизвестного комплекса сейсмогравитационных дислокаций в долине р. Арыджан, дренирующей восточный макросклон Чаган-Узунского массива - новейшего горста, разделяющего Курайскую и Чуйскую межгорные впадины. Уплощенная поверхность массива, состоящего из блоков более высокого порядка, имеет уклон в сторону Чуйской впадины, при этом максимальными высотными отметками характеризуются блоки в северной и западной частях массива - до 2926 м (гора Сукор). Они же несут следы наиболее значительной ледниковой эрозии. По данным повторного нивелирования (для двух эпох измерений 2-го класса: 1939-1978 гг. и 1978-1993 гг.), Чаган-Узунский горст, на современном этапе развивающийся с западной частью Чуйской впадины как единая структура, характеризуется самыми высокими скоростями вертикальных движений на участке от устья р. Чуя до восточной части Чуйской впадины - 7.84-8.0 мм/год [Рогожин, Платонова, 2002]. Южная разломная граница именно этого поднятия была активизирована в ходе Чуйского землетрясения 2003 г. $\left(M_{s}=7.3\right)$, в его пределах зафиксированы эпицентры афтершоков Чуйского землетрясения [Еманов и др., 2009; Лескова, Еманов, 2013] и землетрясений 1960 и 1988 гг. с магнитудой порядка 4.0. О сейсмотектонической активности Чаган-Узунского массива в голоцене свидетельствуют комплексы обвалов, оползней, осовов, маркирующих его границы по всему периметру (рис. 1). Наиболее крупная многофазная Сукорская сейсмодислокация, возникшая предположительно еще в конце позднеледниковья, осложняет высокий и крутой северный макросклон Чаган-Узунского массива. Вдоль этого же макросклона отмечен еще ряд обвалов, вызывавших подпруживание русла Чуи в раннем голоцене [Бутвиловский, 1993]. 


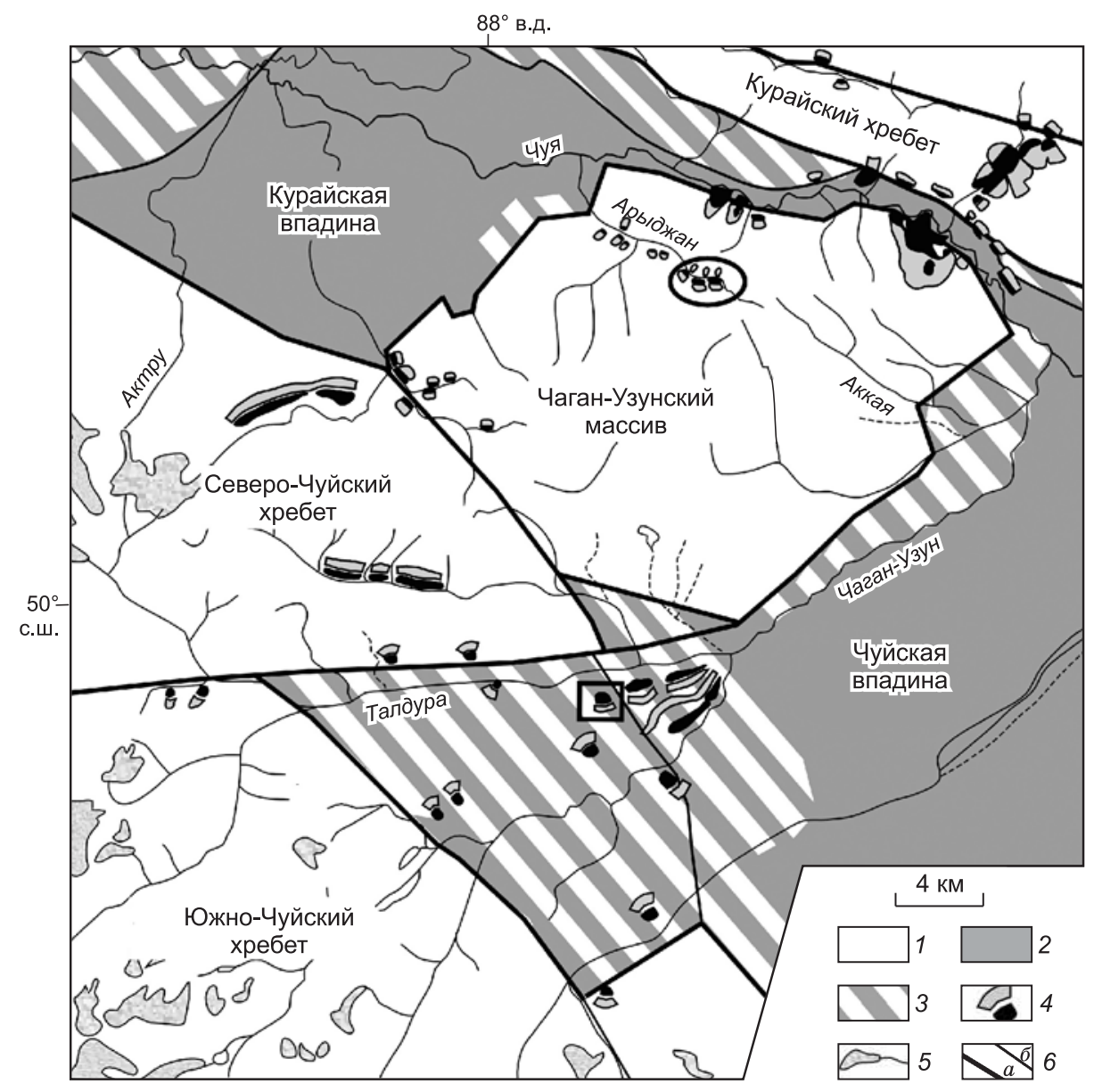

Рис. 1. Комплексы крупных обвалов, оползней, осовов маркируют разломные границы ЧаганУзунского межвпадинного выступа и свидетельствуют об их сейсмической активности в конце позднего плейстоцена-голоцене.

Квадратом отмечен оползень, сошедший в эпицентральной зоне Чуйского землетрясения 2003 г., овалом — рассматриваемый в статье комплекс обвалов в долине р. Арыджан. 1 - хребты; 2 - впадины; 3 - вовлеченные в поднятие периферийные части впадин, форберги, отдельные поднятые блоки в структуре впадин; 4 - обвалы, оползни и стенки их отрыва; 5 - ледники и реки; 6 - разломы: $a$ - главные (границы хребтов и впадин), $\sigma$ - второстепенные (границы блоков в структуре хребтов и впадин).

Рассматриваемая долина р. Арыджан расположена также в северной части массива, протягиваясь субпараллельно грабену долины Чуи, разделяющему Чаган-Узунский массив и Курайский хребет. Она выработана в зоне надвигов, разделяющих базальты, кварцево-хлоритовые сланцы, кварциты и алевролиты арыджанской свиты $\left(\mathrm{R}_{3} \mathrm{ar}\right)$, известняки, доломиты и силицилиты баратальской серии $\left(\mathrm{R}_{3}-\mathrm{Vbr}\right)$ и зажатую между ними узкую тектоническую пластину, сложенную алевролитами, известняками и песчаниками курайской свиты $\left(€_{1} \mathrm{kr}\right)$ [Гусев, 2004]. Две серии обвалов зафиксированы в средней и верхней частях долины Арыджана на расстоянии около 1 км друг от друга. Еще одна серия обвалов и крупных осыпей расположена в нижней части долины на удалении 6 км от верхней серии обвалов.

Стенкой отрыва двух наиболее крупных обвалов ( 3.1 и 1.1 млн м³) на левом берегу Арыджана является плоскость реактивированного древнего надвига. Реактивация его широтного фрагмента произошла при заложении серии новейших сдвиговзбросов (рис. 2). Коленообразные изгибы пересекаемых ими русел левых притоков и самого Арыджана указывают на левосдвиговый характер смещения с суммарной амплитудой не менее 50 м. Тектогенные уступы в местах пересечения долин разломами подчеркиваются водопадами (до 10 м высотой в долине Арыджана). Правый склон долины р. Арыджан на широтном участке осложнен несколькими морфологически более свежими и меньшими по размерам незалесенными обвалами, в настоящее время огибаемыми руслом реки (старое русло погребено под обвалами). Выше по долине, на участке северо-западного простирания, правый склон до середины перекрыт мощным осыпным шлейфом, опирающимся основанием на крупнообломочные моренные отло- 
A
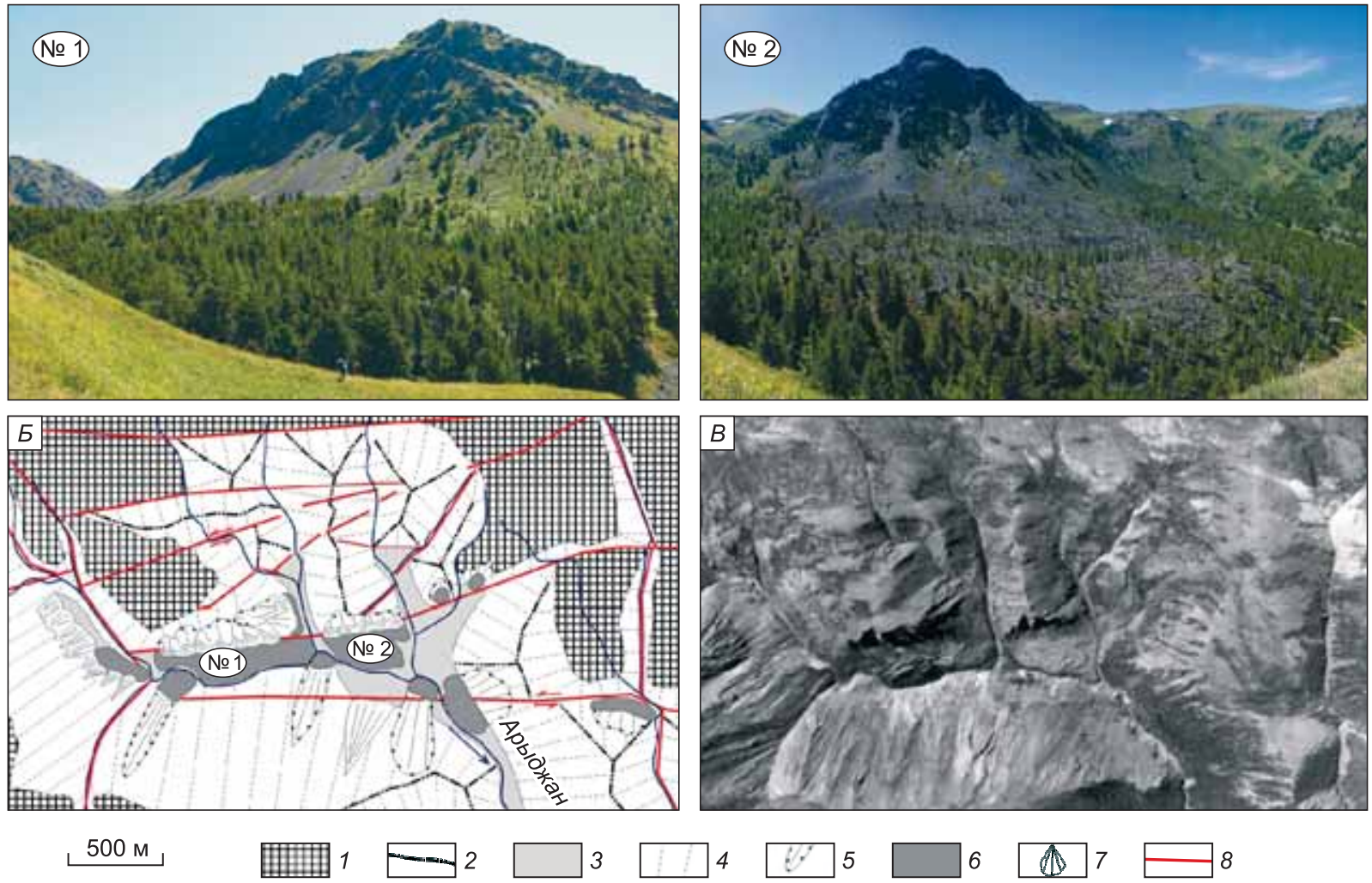

Рис. 2. Обсуждаемый в работе комплекс сейсмообвалов в долине р. Арыджан.

№ 1 - верхний и № 2 - нижний по течению обвалы $(A)$; геоморфологическая схема $(Б)$ и аэрофотоснимок района исследования $(B) .1$ - уплощенные водоразделы со следами ледниковой экзарации; 2 - гребневидные водоразделы; 3 - днище долин; 4 - склоны долин и сейсмотектонические уступы; 5 - стенки отрыва обвалов; 6 - тела обвалов; 7 - осыпи; 8 - разломы.
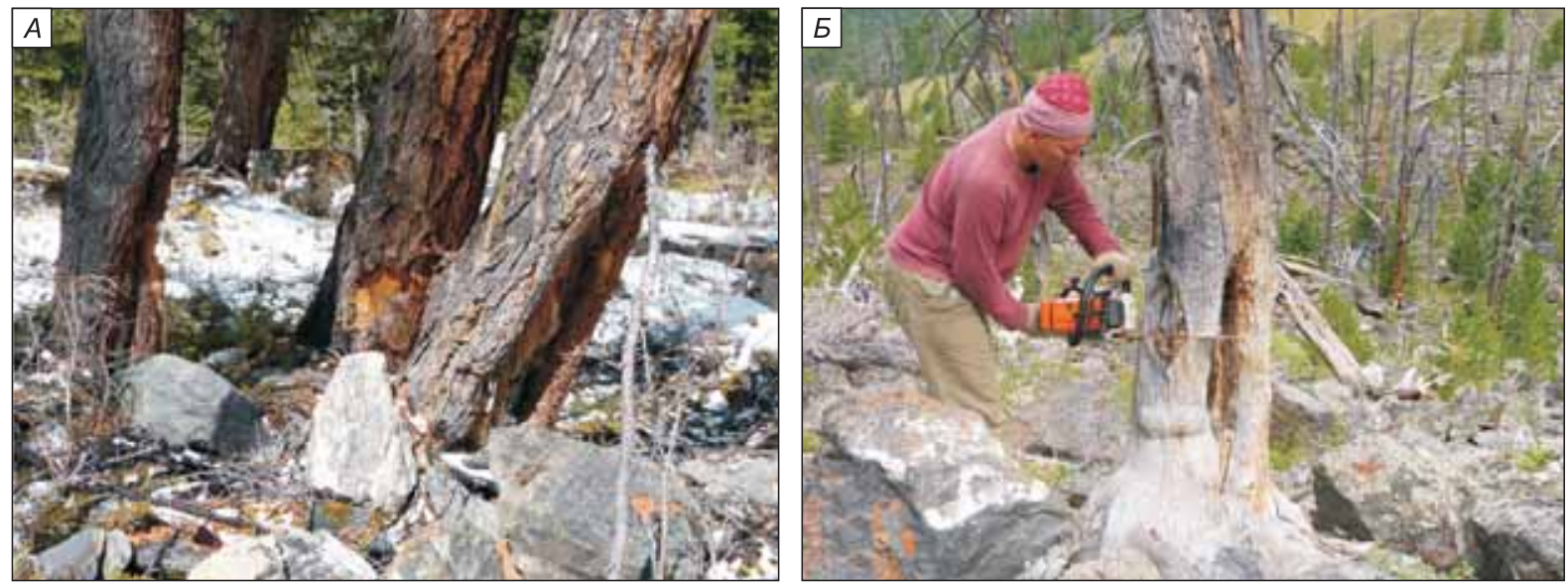

Рис. 3. Деревья, произрастающие на осыпях и обвалах и получившие множественные травмы во время камнепадов.

$A$ - деревья, травмированные в ходе Чуйского землетрясения в 2003 г.; 5 - деревья с палеотравмами.

жения, выполняющие днище долины. Ряд более мелких обвалов расположен ниже границы леса у подножий обоих склонов долины Арыджана.

Высокая концентрация крупных и мелких обвалов скальных пород на небольшой площади, отсутствие зависимости их расположения от экспозиции склонов, состава и возраста слагающих склоны пород, приуроченность к разломам и узлам их сочленения, сочетание обвалов с сейсморвами на водо- 
разделах и склонах долин указывают на сейсмическое происхождение данных форм рельефа. Весьма вероятно, что верхний участок долины Арыджана представлял собой эпицентральную зону одного или нескольких сильных голоценовых землетрясений, в ходе которых на данном участке происходило обрушение левого склона долины. При обследовании долины в 2009 г. в ее верховьях нами были обнаружены следы Чуйского землетрясения 2003 г. — «выпрыгнувшие» из дерна валуны на днище долины; мелкие трещины и разрывы дерна; небольшие свежие срывы поверхностного слоя склоновых отложений вместе с дерном; подновление осыпей; многочисленные свежие травмы на деревьях, произрастающих на обвалах вблизи стенок отрыва; следы ударов обломков, сорвавшихся со скальных склонов. Именно здесь был зафиксирован эпицентр одного из афтершоков Чуйского землетрясения [Еманов и др., 2009].

Наиболее крупные обвалы, выбранные нами в качестве объекта дендросейсмологических исследований, расположены на склоне северной экспозиции на абсолютных высотах 2250-2200 и 21702130 м (№ 1 и № 2 соответственно). Оба обвала сложены глыбами кварцево-хлоритовых сланцев с редкими обломками диоритов, в верхнем по течению обвале встречаются обломки темно-серых мраморизованных известняков с кварцевыми жилами. Верхний обвал имеет лучшую сохранность и налегает на более древние обвальные отложения. Нижний, по всей видимости, более древний обвал уже приобрел черты каменного глетчера, однако и в его строении можно выделить несколько генераций. Поверхность обоих обвалов покрыта лесом. Лесообразующей породой в долине р. Арыджан на этой высоте является сосна сибирская (Pinus sibirica Du Tour). Отдельные деревья заселили опирающиеся на обвалы осыпи и каменные потоки. Лес на обвале № 2 пострадал от пожара. Следы пожара сохранились и на обвале № 1, но в меньшем масштабе. К сожалению, не удалось взять образцы с деревьев, переживших пожар и имеющих пожарные повреждения, поэтому они были отобраны с погибших деревьев. Исходя из того, что остатков коры по внешнему периметру у образцов не сохранилось, можно сделать вывод, что пожар произошел не ранее 1945 г. (и не позднее 1973 г., когда были сделаны аэрофотоснимки этой территории). Верхняя граница леса в данной части ЮВ Алтая проходит несколько выше поверхности обвалов, однако стенка отрыва верхнего по течению обвала, высота которой достигает 150 - 170 м, вследствие крутизны и осыпания лесной растительностью не освоена. Более пологая стенка отрыва нижнего, более старого, обвала заселена отдельными деревьями.

\section{СТРАТЕГИЯ ОТБОРА ОБРАЗЦОВ И МЕТОДИКА ДЕНДРОХРОНОЛОГИЧЕСКОГО ДАТИРОВАНИЯ}

Исходные посылки. Анализ расположения и морфологии сейсмообвалов, так же как и датирование разрывных нарушений, свидетельствуют о многократных активизациях одних и тех же фокальных зон на территории ЮВ Алтая [Рогожин, Платонова, 2002; Агатова и др., 2006; Рогожин и др., 2007, Непоп, Агатова, 2008]. Исходя из этого, помимо определения времени начала заселения обвалов лесом и, как следствие, установления минимального возраста сейсмодеформаций, нами был опробован новый способ датирования сейсмособытий, происходивших в исследуемом районе уже после формирования лесного покрова на поверхности обвалов. Мы предположили, что травмы, полученные деревьями, произраставшими вблизи стенок отрыва, могут являться следами последующих сейсмоиндуцированных камнепадов (по аналогии с деревьями, травмированными в 2003 г.) (рис. 3). При построении длительных абсолютных локальных д.к.х. или использовании региональной д.к.х. Mongun появляется возможность датирования проникающих повреждений древесины не только современных, но и палеодеревьев на интервале, превышающем период повторяемости сильных землетрясений в данном районе. Очевидно, что камнепады могут иметь и климатическую природу и быть вызваны сильными дождями либо таянием снега. Именно поэтому необходимо было сформулировать критерий выделения сейсмоиндуцированных камнепадов. Таким критерием сейсмической природы выявляемых при анализе древесины камнепадов мы полагаем синхронность получения множественных травм деревьями на разных обвалах (на разных участках активизированной сейсмозоны).

Метод датирования травм древесины в горных районах известен давно, но анализ возраста травм использовался до сих пор в дендрогеоморфологии для выявления периодов климатически обусловленного усиления склоновых процессов в спокойной сейсмической обстановке [Stoffel, Bollschweiler, 2008], и предлагаемый подход является новым в дендросейсмологических исследованиях.

Так как выявляемые на основании дендрохронологических данных годы резкой активизации камнепадов являются лишь предполагаемыми датами землетрясений, перед нами также стояла задача подтверждения реальности выделяемых таким образом сейсмических событий и их датирования альтернативным методом.

Стратегия отбора образцов. Отбору образцов предшествовало детальное полевое и дистанционное палеосейсмогеологическое исследование с картированием сейсмогравитационных и сейсмотектонических нарушений рельефа, необходимое для обоснования сейсмической природы датируемых обвалов. 

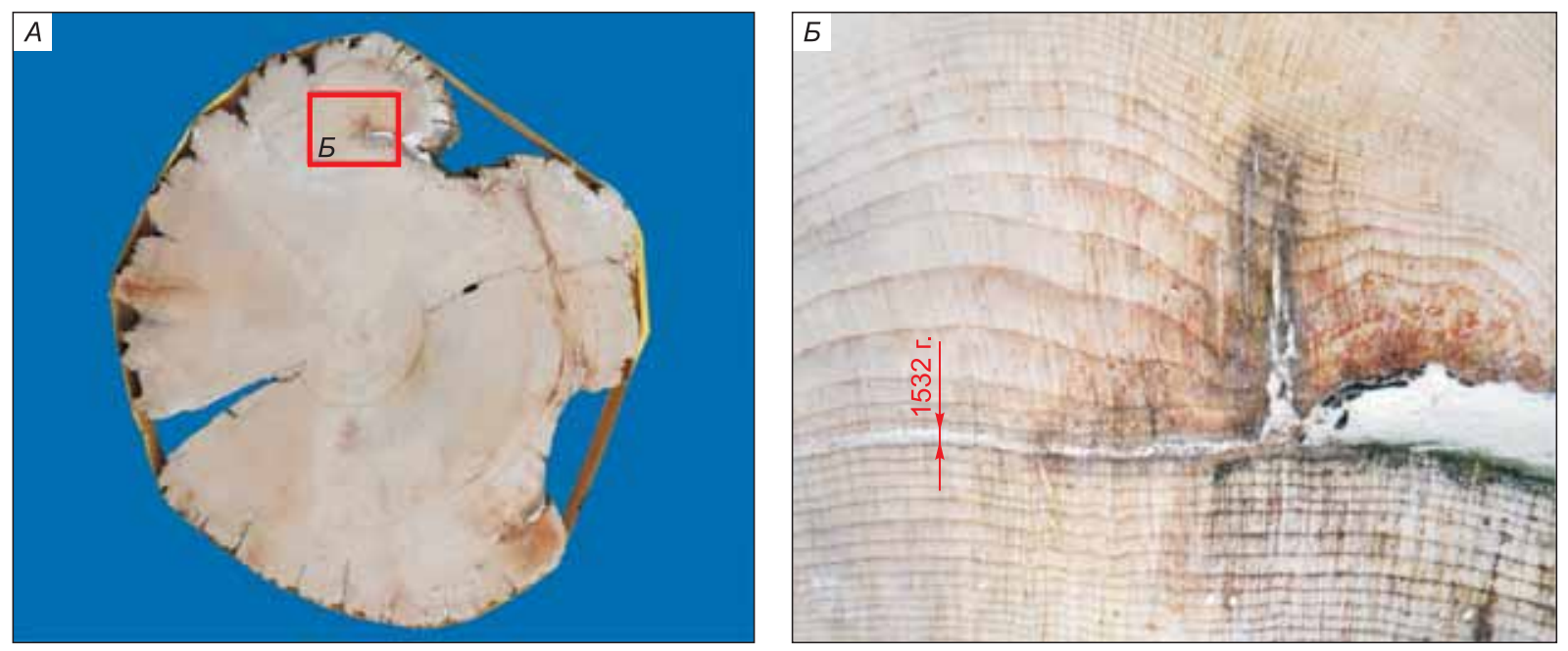

Рис. 4. Спил травмированного дерева $(A)$ и изменение структуры годичных колец после получения травмы в 1532 г. (Б).

Далее выделяли поверхности обвального и осыпного происхождения, наиболее близкие по высоте к верхней границе леса. При этом среди скальных обвалов были выбраны максимальные по размерам, что является одним из аргументов в пользу их сейсмической природы.

Отбор образцов проводили с учетом необходимости построения максимально длительной древесно-кольцевой хронологии и получения представительной выборки травм древесины. Образцы отбирали как на осыпях, так и с поверхности обоих обвалов вблизи стенок отрыва и наиболее активных осыпных лотков. Среди стоящих (как живых, так и погибших) травмированных деревьев выбирали те, которые имели проникающие травмы на обращенной к склону стороне ствола и сторонах, задеваемых во время камнепадов по касательной (см. рис. $3, A$ ). С живых деревьев отбирали образцы в виде клиновидных выпилов, а с погибших в местах травм - поперечные спилы. Для обеспечения надежности датировки образцов с повреждениями с целых участков выше по стволу делали дополнительные спилы. Для календарной привязки образцов палеодревесины была построена древесно-кольцевая хронология по кернам, отобранным с живых деревьев, не имеющих поверхностных повреждений.

Места отбора образцов фиксировали с помощью GPS приемника. Проводилась фотодокументация мест отбора, деревьев, с которых брались спилы и керны, а также поверхностей полученных спилов. обвалов.

Всего был отобран 61 образец - 49 сегментов с нижнего и 12 сегментов с верхнего по течению

Методика датирования. Предварительно у образцов зачищали торцовую поверхность с последующим выбором двух и более радиусов для измерений ширины годичных колец. Измерения радиального прироста были проведены на установке LINTAB 5. На основе стандартной процедуры кросскорреляционного анализа в специализированном программном пакете для дендрохронологических исследований DPL [Holmes, 1983] и графической перекрестной датировки в программном пакете TSAP system V3.5 [Rinn, 1996] с визуальным сопоставлением кривых изменчивости абсолютных и индексированных значений радиального прироста были датированы полученные древесно-кольцевые серии. Результаты измерений нескольких образцов, отобранных с одного дерева, сводились в обобщенную серию, и в конечной выборке каждое дерево было представлено одной д.к.х. Возрастной тренд из древесно-кольцевых серий был удален на основе использования негативной экспоненты и сплайна в две трети от длины индивидуальной хронологии в программе ARSTAN [Cook, Krusic, 2008].

Фиксация повреждений структуры годичного кольца производилась визуально с помощью микроскопа (рис. 4). После определения положения поврежденного годичного кольца на образце производилось измерение двадцати колец до и пятидесяти после травмы с последующей перекрестной датировкой, что обеспечило верификацию дат повреждений. Результаты датирования и определения характера выявленных травм (единичные либо множественные), полученных деревьями на обоих обвалах, были представлены в графическом виде. 


\section{РЕЗУЛЬТАТЫ И ДИСКУССИЯ}

Определение минимального возраста сейсмообвалов в долине р. Арыджан и даты предполагаемого средневекового землетрясения. В результате применения стандартной процедуры древеснокольцевого анализа для долины р. Арыджан была построена д.к.х. по сосне сибирской (Pinus sibirica Du Tour) длительностью 1154 года (с 856 по 2009 г.), которая использовалась для календарной датировки образцов со следами повреждений (рис. $5, A$ ). Всего после процедуры отбраковки были проанализированы травмы у 36 деревьев - 30 деревьев с № 1 и 6 с № 2 .

Согласно полученным данным, заселение верхнего и нижнего по течению обвалов произошло не позднее 1069 и 856 гг. н.э. соответственно. С учетом времени формирования и стабилизации перекрывающих обвалы осыпей, а также их заселения лесом (в условиях ЮВ Алтая время заселения новообразованных каменных поверхностей лесной растительностью может составлять 100 лет и более) можно предположить, что к 600-700 гг. н.э. последние генерации обвалов уже существовали. В настоящее время имеющийся материал не позволяет однозначно разделить обвалы № 1 и № 2 по времени возник-

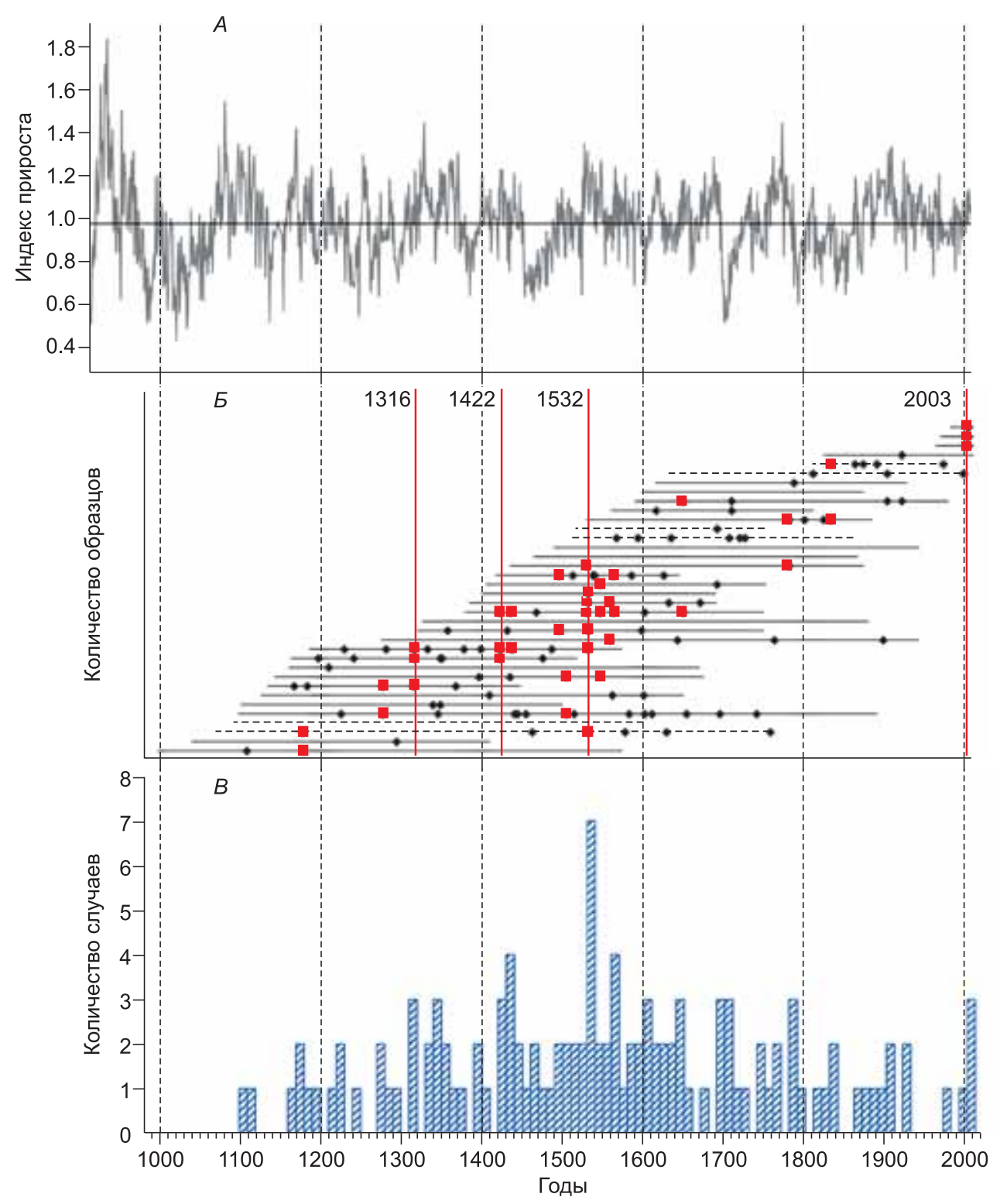

\section{Рис. 5. Распределение повреждений древесины на древесно-кольцевых сериях.}

$A$ - стандартизированная древесно-кольцевая хронология, построенная для участка Арыджан; $D$ - распределение повреждений древесной структуры на образцах; $B$ - частота встречаемости повреждений на деревьях по десятилетиям. 5 - штриховой линией обозначены серии прироста деревьев с обвала № 1, сплошной - с обвала № 2. Красными квадратами указаны повреждения, зафиксированные у двух и более деревьев, черными ромбами обозначены случайные повреждения. 
новения. По всей видимости, их формирование было связано с активизациями Арыджанского сдвига, сопряженного с одним из разломов в структуре Курайской впадины. Возможно, эти подвижки являлись следствием сейсмотектонической активности разломных границ Чаган-Узунского блока и/или хребтов, обрамляющих Курайско-Чуйскую систему впадин.

Из 120 зафиксированных повреждений структуры годичного кольца по три и более совпадений приходится на 1316, 1422, 1532 и 2003 годы. При этом в 1532 г. деревья оказались травмированы на обоих обвалах (см. рис. 5, Б). Подчеркнем, что на обвале № 1 образцов было отобрано значительно меньше, чем на обвале № 2, тем не менее камнепад, произошедший в 1532 г., привел к травмам деревьев, представленных и в малой выборке. Следовательно, столь резкое усиление склоновых процессов могло быть инициировано землетрясением. Тот факт, что поврежденные в 1532 г. деревья получили множественные травмы на разной высоте от комлевой части ствола, является свидетельством силы предполагаемого сейсмособытия и/или близкого положения его эпицентра к изучаемому участку. Таким образом, весьма вероятно, что, как и в 2003 г., в 1532 г. были активизированы границы Чаган-Узунского блока. Увеличение объема выборок на изученных обвалах и проведение площадных дендросейсмологических исследований на территории ЮВ Алтая позволит более определенно судить о природе сильных камнепадов, травмировавших деревья в 1316 и 1422 гг. на обвале № 2.

Верификация результатов дендрохронологического анализа методом радиоуглеродного датирования. Определение лишь верхнего временного рубежа формирования наиболее крупных обвалов в долине р. Арыджан не позволяет однозначно соотнести их с каким-либо одним из выявленных палеосейсмогеологическим методом землетрясений в пределах ЮВ Алтая. Так как возникновение этих обвалов может быть отнесено к 600-700 гг. н.э, наиболее вероятно, они связаны с древними землетрясениями, приводившими к разрывам и сопутствующим деформациям палеопочв в долине р. Кускуннур и на водоразделе рек Кускуннур и Талдура (урочище Узюк). Следы этих палеосейсмособытий были вскрыты сейсмотрещинами Чуйского землетрясения 2003 г. Здесь Е.А. Рогожиным с соавторами [2007] описаны палеопочвы в погребенных под грубообломочным материалом клиньях и древних захороненных валах вспучивания, имеющие радиоуглеродный возраст $1280 \pm 30,1160 \pm 30,1100 \pm 30$ лет (обр. ИГАН 2818, 2980, 2983). Сходный возраст имеет почва в коллювиальном клине вдоль эскарпа у подножия северного склона Центрально-Курайской антиклинальной гряды (новейшего поднятия типа форберга в днище Курайской межгорной впадины) - $1040 \pm 80$ лет (ГИН 9082), который также интерпретируется как возраст одного из сильных землетрясений [Рогожин, Платонова, 2002]. Проведенная нами калибровка этих дат $(1219 \pm 70,1077 \pm 96,1000 \pm 63 \text { и } 976 \pm 195 \text { лет соответственно) })^{2}$ свидетельствует о том, что сильные землетрясения, вызвавшие описанные деформации, происходили в ЮВ Алтае в интервале 661-1169 гг. н.э. По всей видимости, с какими-то из этих сейсмособытий и было связано возникновение рассматриваемых обвалов (либо их последних генераций) в долине р. Арыджан.

Вероятность ранее неизвестного сильного средневекового землетрясения 1532 г., следы которого были идентифицированы дендрохронологическим методом в северной части Чаган-Узунского горста, подтверждается радиоуглеродными датами горизонтов палеопочв, нарушенных древними сейсморазрывами и перекрывающих их ненарушенных, в зоне сочленения этого неотектонического блока с Чуйской впадиной и Южно-Чуйским хребтом. Многочисленные древние сейсморазрывы были обнаружены нами при обследовании стенок современных разрывов в теле оползня, сошедшего в 2003 г. в эпицентральной зоне Чуйского землетрясения в долине р. Талдура, что еще раз подтверждает корректность вывода о многократных активизациях очаговых зон в пределах ЮВ Алтая. Возраст деформированных нижнего и верхнего почвенных горизонтов составляет $2234 \pm 119(2240 \pm 60$, ИГАН 4090) и $848 \pm 111(950 \pm 60$, ИГАН 4105) лет соответственно, возраст перекрывающего их ненарушенного горизонта $-297 \pm 27$ лет $(250 \pm 30$, СОАН 8659$)$. Таким образом, предполагаемое по результатам дендрохронологического анализа сейсмособытие 1532 г. попадает в интервал 1000-1680 гг. н.э., установленный радиоуглеродным методом. Косвенным подтверждением этого сильного средневекового землетрясения является радиоуглеродная дата погребенного под коллювиальными отложениями почвенного горизонта, вскрытого в стенке отрыва современного сейсмооползня в долине р. Талдура $-370 \pm 30$ лет (ИГАН 3007 [Рогожин и др., 2007]), которая после проведенной нами калибровки дает возраст $410 \pm 93$ лет, или $1540 \pm 93$ г. н. э. В Курайской впадине в 2 км западнее с. Курай траншеей был вскрыт полутораметровый эскарп активного разлома на южном крыле Центрально-Курайской антиклинальной гряды. Зона палеосейсморазрыва представляет собой в разрезе серию из трех-четырех крутых и пологих взбросов [Рогожин, Платонова, 2002]. Возраст щепок и древесного угля из горизонтов торфа, рассеченных взбросами (388 \pm 82

2 Калибровка радиоуглеродного возраста проведена в программе Calib Radiocarbon Calibration Program [Stuiver, Reimer, 1993] версии REV 5.0.1 [Reimer et al., 2004]. Возраст рассчитан от 1950 г. Интервал калиброванного возраста приведен на $2 \sigma$. Далее по тексту, если не оговорено иное, дается калиброванный таким образом возраст образца, а в скобках приводится его радиоуглеродный возраст и лабораторный номер. 
$(324 \pm 30$, ИГАН 1692$)$ и $399 \pm 86$ (345 \pm 30 , ИГАН 1702) лет), указывает на формирование зоны этого палеосейсморазрыва позднее 1466 г. н.э. ${ }^{3}$ Таким образом, следы сильного средневекового землетрясения фиксируются на стыке границ Чаган-Узунского массива с Чуйской впадиной и Южно-Чуйским хребтом, во внутренней структуре Чаган-Узунского горста вдоль его северной разломной границы (в долине Арыджана), а также на южной границе новейшего поднятия в днище Курайской впадины. Прослеживание на космоснимках южного эскарпа Центрально-Курайской антиклинальной гряды на 7075 км позволило оценить магнитуду данного землетрясения равной или превышающей 7.5 [Рогожин, Платонова, 2002].

Уточнение периода повторяемости сильных землетрясений на территории ЮВ Алтая в голоцене и последние 3 тыс. лет. Разворачивание региональной стационарной сети сейсмостанций на территории Горного Алтая, начавшееся в 1962 г., и значительный объем полученного материала по зарегистрированным с тех пор землетрясениям позволил провести сейсмическое районирование территории по комплексу геолого-тектонических и сейсмологических данных и оценить период повторяемости сильных землетрясений в 1-3 тыс. лет [Жалковский и др., 1978].

В 1996-1999 гг. было проведено масштабное палеосейсмогеологическое изучение, направленное на выявление и определение абсолютного возраста древних сейсмогенных нарушений рельефа. Результаты этих исследований подтвердили полученную ранее оценку для Курайско-Чуйской сейсмоактивной зоны [Рогожин, Платонова, 2002].

Произошедшее в 2003 г. Чуйское землетрясение с $M_{s}=7.3$, сильнейшее за весь период инструментальных наблюдений, не только дало возможность провести исследование возникших деформаций рельефа, но и заставило вновь обратиться к изучению следов древних сильных землетрясений. Был уточнен период их повторяемости - 500-900 лет за последние 9 тыс. лет [Рогожин и др., 2007].

Заметим, что в приведенных работах не проводилась калибровка многочисленных радиоуглеродных дат, что вносит неточность при привязке характеризуемых ими событий к календарной шкале времени. Проведенная нами калибровка всех ранее опубликованных датировок и представленные в данной работе новые данные позволяют уточнить период повторяемости сильных землетрясений в этом сейсмоактивном районе, который составляет около 800 лет в последние 9 тыс. лет и около 600 лет во второй половине голоцена. При этом за последние 3 тыс. лет период повторяемости сильных землетрясений составил $\sim 400$ лет. Для расчета этих величин, помимо ранее опубликованных [Рогожин и др., 2007], мы использовали только дату средневекового землетрясения 1532 г., так как точные даты формирования обвалов в долине р. Арыджан не установлены и привязка их к определенному сейсмособытию затруднена.

Следует отметить, что частота установленных палеосейсмогеологическим методом землетрясений в первой половине голоцена значительно ниже, чем во второй. Это может объясняться как неполной сохранностью следов более древних землетрясений, так и сложностью разделения по времени проявлений молодых сейсмособытий вследствие погрешности радиоуглеродного метода.

\section{ЗАКЛЮЧЕНИЕ}

В данной статье на примере юго-восточной части Горного Алтая впервые показана возможность использования длительных древесно-кольцевых хронологий для определения верхней временной границы формирования палеосейсмообвалов и установления точных дат землетрясений, вызывающих проникающие травмы древесины. Сформулирован критерий выделения сейсмоиндуцированных камнепадов, позволяющий выявлять их среди камнепадов другой природы. Полученные с помощью дендрохронологического анализа даты землетрясений - не позднее 1069 и 856 гг. н.э. (предположительно около 600-700 гг. н.э.) и 1532 г. — подтверждены радиоуглеродным методом датирования сейсмодеформированных почвенных горизонтов. С учетом новых данных и калибровки ранее полученных радиоуглеродных дат уточненный период повторяемости древних землетрясений ЮВ Алтая в голоцене составляет 400-700 лет, что еще раз подтверждает корректность отнесения этой части Алтая к территориям с высоким уровнем сейсмической опасности.

Данная работа является первым опытом дендросейсмологических исследований в пределах Горного Алтая и определяет направление будущих работ в этой области. Увеличение выборок и проведение масштабных площадных исследований позволит уточнить даты и период повторяемости сильных землетрясений ЮВ Алтая в последние 2500-3000 лет.

3 Е.А. Рогожин и С.Г. Платонова [2002] трактовали эти даты как доказательство очень молодого возраста (не ранее 1700 г. н.э.) вскрытых траншеей активных взбросов, так как для интерпретации ими были использованы некалиброванные даты. Однако калиброванный возраст дат свидетельствует о более древнем возрасте сейсмособытия, с которым связан данный сейсморазрыв. Процедура калибровки является необходимой для привязки радиоуглеродных дат и характеризуемых ими событий к календарной шкале времени. 
В целом предлагаемые разработки важны как в прикладном аспекте - для изучения палеосейсмичности конкретного горного региона, так и в методическом - для датирования свидетельств сильных землетрясений прошлого в районах, где отсутствуют продолжительные исторические летописи, а сейсмологические наблюдения не превышают нескольких десятилетий.

Работа выполнена в рамках планов НИР ИГМ СОРАН, при поддержке РФФИ (грант 13-05-00555) и гранта президента РФ МК-1675.2011.6.

\section{ЛИТЕРАТУРА}

Агатова А.P., Непоп Р.К., Высоцкий Е.М. Сейсмогравитационные палеодислокации в долине реки Чаган (Юго-Восточный Алтай) // Геоморфология, 2006, № 4, с. 53-62.

Агатова А.P., Непоп Р.К., Баринов В.В., Назаров А.Н., Мыглан В.С. Новый аспект применения дендрохронологического анализа для датирования сильных землетрясений прошлого (на примере Горного Алтая) // ДАН, 2014, т. 455, № 2, с. 175-178.

Бутвиловский В.В. Палеогеография последнего оледенения и голоцена Алтая: событийно-катастрофическая модель. Томск, Изд-во Том. ун-та, 1993, 253 с.

Вагнер Г.А. Научные методы датирования в геологии, археологии и истории. М., Техносфера, 2006, 576 c.

Высоцкий Е.М., Новиков И.С., Агатова А.Р., Гибшер А.С. Плейстосейстовая область и тектоническая позиция очага Чуйского землетрясения 2003 года // ДАН, 2004, т. 395, № 4, с. 499-502.

Гусев А.И. Карта полезных ископаемых и закономерностей их размещения (Республика Алтай). М-б 1:500 000. ФГУП «Горно-Алтайская ПСЭ», 2004.

Еманов А.А., Лескова В.Е., Еманов А.Ф., Фатеев А.В. Элементы структуры и фазы развития афтершокового процесса Чуйского землетрясения // Физическая мезомеханика, 2009, т. 12, № 1, с. 29-36.

Жалковский Н.Д., Чернов Г.А., Мучная В.И. Сейсмическое районирование территории АлтаеСаянской горной области // Сейсмогеология восточной части Алтае-Саянской горной области. Новосибирск, Наука, 1978, с. 79-90.

Лескова Е.В., Еманов А.А. Иерархические свойства поля тектонических напряжений в очаговой области Чуйского землетрясения 2003 года // Геология и геофизика, 2013, т. 54 (1), с. 113-123.

Мыглан В.С., Ойдупаа О.Ч., Ваганов Е.А. Построение 2367-летней древесно-кольцевой хронологии для Алтае-Саянского региона (горный массив Монгун-Тайга) // Археология, этнография и антропология Евразии, 2012, № 3, с. 76-83.

Назаров А.Н., Соломина О.Н., Мыглан В.С. Динамика верхней границы леса и ледников Центрального и Восточного Алтая в голоцене // ДАН, 2012, т. 444, № 6, с. 671 - 675.

Нарожный Ю.К., Осипов А.В. Ороклиматические условия оледенения Центрального Алтая // Изв. РГО, 1999, т. 131, вып. 3, с. 49-57.

Непоп Р.К., Агатова А.Р. Первый опыт использования оползневых сейсмодеформаций для оценки магнитуд палеоземлетрясений на территории Юго-Восточного Алтая // Геология и геофизика, 2008, т. 49 (2), с. $188-199$.

Новиков И.С. Морфотектоника Алтая. Новосибирск, Изд-во СО РАН, филиал «Гео», 2004, 313 с.

Ребецкий Ю.Л., Кучай О.А., Маринина А.В. Напряженное состояние и деформации земной коры Алтае-Саянской горной области // Геология и геофизика, 2013, т. 54 (2), с. 271-291.

Рогожин Е.А., Платонова С.Г. Очаговые зоны сильных землетрясений Горного Алтая в голоцене. М., Изд-во ОИФЗ РАН, 2002, 130 с.

Рогожин Е.А., Овсюченко А.Н., Мараханов А.В., Ушанова Е.А. Тектоническая позиция и геологические проявления Алтайского землетрясения // Геотектоника, 2007, № 2, с. 3-22.

Ружич В.В., Саньков В.А., Днепровский Ю.И. Дендрохронологическое датирование сейсмогенных разрывов в Становом нагорье // Геология и геофизика, 1982 (8), с. $62-69$.

Слюсаренко И.Ю. Дендрохронологическое датирование археологических памятников скифской эпохи Алтая: Автореф. дис. ... к.и.н. Новосибирск, ИАЭТ СО РАН, 2010, 34 с.

Солоненко В.П. Палеосейсмогеологический метод // Живая тектоника, вулканы и сейсмичность Станового нагорья. М., Наука, 1966, с. 15-35.

Cook E.R., Krusic P.J. A tree-ring standardization program based on detrending and autoregressive time series modeling, with interactive graphics (ARSTAN). 2008, http://www.ldeo.columbia.edu/res/fac/trl/public/ publicSoftware.html.

Holmes R.L. Computer-assisted quality control in tree-ring dating and measurement // Tree-ring bull., 1983, v. 44, p. 69-75.

Paleoseismology / Ed. J.P. McCalpin. $2^{\text {nd }}$ ed. San Diego, Elsevier, 2009, 613 p. 
Reimer P., Baillie M., Bard E., Bayliss A., Beck J., Bertrand C., Blackwell P., Buck C., Burr G., Cutler K., Damon P., Edwards R., Fairbanks R., Friedrich M., Guilderson T., Hughen K., Kromer B., McCormac F., Manning S., Ramsey C.B., Reimer R., Remmele S., Southon J., Stuiver M., Talamo S., Taylor F., Plicht J.V.D., Weyhenmeyer C. IntCal04 terrestrial radiocarbon age calibration, 0-26 cal kyr BP // Radiocarbon, 2004, v. 46, p. 1029-1058.

Rinn F. TSAP V3.5. Computer program for tree-ring analysis and presentation. Heidelberg, Frank Rinn Distribution, 1996, 264 p.

Stoffel M., Bollschweiler M. Tree-ring analysis in natural hazards research - an overview. Natural hazards and Earth system // Sciences, 2008, v. 8, p. 187-202.

Stuiver M., Reimer P.J. Extended C-14 data-base and revised Calib 3.0 C-14 age calibration program // Radiocarbon, 1993, v. 35, p. 215-230. 